\title{
LIMITED TIMES: RETHINKING THE BOUNDS OF COPYRIGHT PROTECTION
}

\author{
KEVIN A. GOLDMAN ${ }^{\dagger}$ \\ INTRODUCTION
}

No one born in the last eighty years has seen an original work created in her lifetime fall into the public domain. ${ }^{1}$ Each time the term of copyright protection has been due to expire, Congress has passed another extension. ${ }^{2}$ This has led some scholars to suggest that Congress is effectively granting these works a perpetual copyright, in violation of the Constitution's requirement that such protection only be granted for "limited Times." Although the Supreme Court has re-

${ }^{\dagger}$ A.B. 1999, Dartmouth College; J.D. Candidate 2006, University of Pennsylvania. I am grateful to Rachel Brodin, William Bryson, David Castleman, Seth Kreimer, Gideon Parchomovsky, Robert Potter, Kermit Roosevelt, Jake Shields, and Polk Wagner for providing useful suggestions and thoughtful criticism. Any errors and opinions are mine alone.

${ }^{1}$ More precisely, no work has fallen into the public domain so long as the copyright holder maintained her exclusive rights. Any pre-1976 Copyright Act works whose initial twenty-eight-year term of protection expired might have passed into the public domain if the copyright holder chose not to exercise the renewal option. See Act of Mar. 4, 1909, ch. 320, § 23, 35 Stat. 1075, 1080 (providing for a twenty-eight-year term of protection for copyrighted works and a twenty-eight-year renewal term) (repealed 1976); see also Copyright Act of 1976, Pub. L. No. 94-553, 90 Stat. 2541, 2572 (codified as amended at 17 U.S.C. $\$ 302(2000)$ ) (instituting terms of copyright protection that extend for the life of the author plus fifty years for works created on or after January 1 , 1978). But see Copyright Renewal Act of 1992, Pub. L. No. 102-307, 106 Stat. 264, 266 (codified as amended at 17 U.S.C. \$ 304(a) (2000)) (making copyright renewal automatic for copyrights in their first term on January 1, 1978). Similarly, copyright owners are free to submit their works to the public domain prior to their expiration. See, e.g., Creative Commons, Public Domain Dedication, http://creativecommons.org/ licenses/publicdomain/ (last visited Jan. 20, 2006) (providing a model license whereby a copyright owner may release a protected work into the public domain).

${ }^{2}$ By some counts, this has occurred eleven times since 1962. See LAWRENCE LESSig, Free Culture: How Big Media Uses Technology and the LaW to Lock Down Culture AND CONTROL CREATIVITY 134 (2004) ("Eleven times in the last forty years, Congress has extended the terms of existing copyrights ....").

${ }^{3}$ See U.S. CONST. art. I, $\S 8$, cl. 8 (granting Congress the power " $[\mathrm{t}] \mathrm{o}$ promote the Progress of Science and useful Arts, by securing for limited Times to Authors and Inventors the exclusive Right to their respective Writings and Discoveries"); Brief for Pe- 
jected this argument as applied to the current framework, ${ }^{4}$ the constitutionality of future, more dramatic extensions remains an open question. Moreover, given the singular trajectory of congressional action towards ever-increasing duration, an eventual collision with the outer bounds of "limited Times" seems likely. This Comment argues that, rather than resisting this trend, Congress should instead follow the progression to its natural conclusion and enact a regime of indefinitely renewable copyright.

Such a suggestion is anathema to the many scholars who view the ultimate expiration of copyright as a public entitlement and the repeated copyright extensions by Congress as perpetually depriving the public domain. ${ }^{5}$ Yet this conception of the public domain is unduly narrow. Rather than viewing these extensions as Lucy continually pulling the football away just as Charlie Brown is about to kick it, consider instead the similar case of a young child learning to swim. Her father takes a step deeper into the water and says, "Swim to me." Just as she is about to reach him, her father moves farther back and says again, "Swim to me." This process is repeated until the child discovers that she is able to swim on her own, and thus, the tool she thought she needed (the safety of her father's arms) is in fact no longer required.

In a similar fashion, current copyright law gives artists substantial freedom to appropriate from a protected work at the moment of its creation, via doctrines such as fair use $^{6}$ and the idea/expression dichotomy. ${ }^{7}$ It is, of course, impossible to know how life would have been different if revisions to the law had not allowed copyright owners

titioners at 18-32, Eldred v. Ashcroft, 537 U.S. 186 (2003) (No. 01-618) (arguing that Congress's attempt to extend copyright protection retroactively violates the Constitution's "limited Times" provision).

${ }^{4}$ See Eldred, 537 U.S. at 193-94 (holding that Congress did not violate the "limited Times" constraint by enacting a statute that extended the duration of protection for already copyrighted works by twenty years).

${ }^{5}$ See, e.g., LESSIG, supra note 2, at 215-16 ("[I] f Congress has the power to extend existing terms [of copyright protection], then the Constitution's requirement that terms be 'limited' will have no practical effect ... [and] Congress can achieve what the Constitution plainly forbids ....”); JESSICA LITMAN, DIGITAL COPYRIGHT 77-78 (2001) (describing how copyright principles have been reformulated during the past generation in "ways that have expanded copyright's scope and blinded many of us to the dangers that arise from protecting too much, too expansively for too long").

${ }^{6}$ See 17 U.S.C. $\$ 107$ (2000) (describing the fair use exceptions to the exclusive rights of copyright holders); see also infra notes 32-35 and accompanying text (discussing the fair use doctrine).

${ }^{7}$ See Baker v. Selden, 101 U.S. 99, 100-01 (1879) (establishing the idea/ expression dichotomy); see also infra notes 36-37 and accompanying text (discussing the idea/expression dichotomy). 
to keep works of the last eighty years from entering the public domain. But the $\operatorname{arts}^{8}$ have thrived even in the absence of copyright expiration, suggesting that artists have "learned to swim" in a world without what has traditionally been thought of as an expanding public domain.

There is an oft-told tale in the literature of arbitration, describing two brothers involved in a highly contentious dispute over the ownership of an orange. ${ }^{9}$ The arbitrator eventually discovers that both siblings can be appeased, as one brother simply wants to squeeze the fruit for its juice, while the other seeks only the peel in order to make marmalade. While the Coase Theorem might have suggested that it would not matter which brother initially received the orange, ${ }^{10}$ the parable reflects the reality that irrationality will often lead to market failure, ${ }^{11}$ whether the participants are feuding siblings or artists fearful that new technology will destroy their livelihood. ${ }^{12}$ This Comment

\footnotetext{
${ }^{8}$ It is important to note that the words 'art' and 'science' have different connotations today than they did when the Framers wrote that Congress would have the power to "promote the Progress of Science and useful Arts ...." U.S. CONST. art. I, § 8, cl. 8. In 1787, the word 'science' "referred to knowledge in general, in all fields of knowledge," whereas " $[\mathrm{w}]$ hat we mean today by 'science' was then called natural philosophy. It was quite clearly intended by the authors of the Constitution that copyright, not patents, was intended to promote science, and the province of rights granted to inventors respecting their 'Discoveries' was to promote the 'useful Arts." Giles Sutherland Rich, My Favorite Things, 35 IDEA 1, 2 (1994).

${ }^{9}$ See, e.g., Luis Miguel Diaz, Yes-Talk Rule Prevails over Non-Talk Rule in Mediation, in 1 InTERnATIONAL Business Litigation \& ARBitration 425, 429 (PLI Litig. \& Admin. Practice, Course Handbook Series No. H-704, 2004) (describing a different variation of the orange/marmalade story). For a modern gloss, see CMS, CMS GUIDE TO ADR 10 (2003) (comparing the orange/marmalade story to a long-running intellectual property dispute that was eventually settled through arbitration).

${ }_{10}$ See R.H. Coase, The Problem of Social Cost, 3 J.L. \& ECON. 1, 6-8 (1960) (suggesting that resources will be used by the party who values them more, regardless of any legal determination of ownership).

${ }^{11}$ See Jeanne L. Schroeder, The End of the Market: A Psychoanalysis of Law and Economics, 112 HARV. L. REV. 483, 537 (1998) (discussing the role of irrationality in the Coase Theorem).

${ }^{12}$ For example, Jack Valenti, the former chief executive of the Motion Picture Association of America, once claimed that "the VCR is to the American film producer and the American public as the Boston strangler is to the woman home alone." Home Recording of Copyrighted Works: Hearings on H.R. 4783, H.R. 4794, H.R. 4808, H.R. 5250, H.R. 5488, and H.R. 5705 Before the H. Subcomm. on Courts, Civil Liberties, and the Admin. of Justice of the Comm. on the Judiciary, 97th Cong. 8 (1982) (statement of Jack Valenti). Despite these initial fears, the home video market has grown to become a vital revenue stream for the motion picture industry. See, e.g., Di Mari Ricker, "Rio" Raises Copyright Concerns, ENT. L. \& FIN., Dec. 1998, at 1, 1 (noting that the introduction of the VCR
} 
proposes a copyright schema intended to reduce irrationality and maximize social wealth by strengthening the rights most important to traditional content owners, while simultaneously securing the appropriation rights most important to consumers and follow-on artists. ${ }^{13}$ The ultimate insight of this Comment is that, by making copyright protection renewable indefinitely but narrowing the scope of protection to cover only those works that would act as market substitutes for the original work, the realignment of rights and privileges would reflect the current trajectory of the law, and moreover would better serve the dual interests of copyright owners and content users.

This Comment has four parts. Part I traces the evolution of American copyright law. Part II examines the merits of an indefinitely renewable copyright regime. Part III suggests modifications to traditional copyright doctrines that would complement an indefinitely renewable copyright system. Part IV examines various constitutional impediments to creating an indefinitely renewable term of copyright protection.

\section{THE STORY SO FAR: COPYRIGHT LAW, 1790-TODAY}

The history of American copyright law has generally been one of expansion. Although one might expect a legislative body traditionally suspicious of monopolies to continually chip away at the monopolistic $^{14}$ property rights given to copyright owners, for the most part Congress has tended to broaden the scope and duration of protection afforded to authors of creative works.

This Part traces the chronological development of copyright protection, with special emphasis placed on the evolution of protectable subject matter, infringement by derivative works, and the meaning of "limited Times." This examination is not simply intended to establish

\footnotetext{
"spawned a new industry of videocassette rentals and sales that generated more revenues for Hollywood than the sale of movie tickets").

${ }^{13}$ Follow-on artists are artists who incorporate pre-existing works into their own creations. See, e.g., Press Release, Negativland, U2 Negativland: The Case from Our Side (Nov. 10, 1991), reprinted in Negativland, FAIR USE: THE STORY OF THE LeTter U AND THE NUMERAL 2, at 21-25 (1995) (describing Negativland's creative process as follow-on artists).

${ }^{14}$ Intellectual property protection does not provide the holder with a right to use the property, but rather with a right to exclude others from using it. Thus, while copyright protection might confer some monopolistic benefits, it is not a monopoly in the traditional sense. For a general discussion of these ideas, see Edmund W. Kitch, Elementary and Persistent Errors in the Economic Analysis of Intellectual Property, 53 VAND. L. REV. 1727 (2000); John Perry Barlow, The Economy of Ideas, WIRED, Mar. 1994, at 84.
} 
the current state of the law but rather to demonstrate the trajectory along these axes, in order to speculate on their ultimate bounds.

The first federal copyright statute (one of the earliest pieces of legislation enacted by the First Congress in 1790) vested in the author of "any map, chart, book or books ... the sole right and liberty of printing, reprinting, publishing and vending [those works] ... for the term of fourteen years from the time of recording the title thereof in the clerk's office.... ${ }^{15}$ This copyright protection could be renewed for one additional fourteen-year term if the author was still alive at the end of the first term. ${ }^{16}$

These initial limitations-restricting what constituted copyrightable subject matter, providing a short duration of protection, and requiring registration-all seem logically grounded in the utilitarian philosophy expressed in the Promote Progress Clause ${ }^{17}$ and yet reflect the Framers' general distaste for granting commercial monopolies. ${ }^{18}$

In 1831, the subject matter of copyright was expanded to include "musical composition[s]," and the grant of protection was increased to twenty-eight years (again renewable for an additional fourteen-year term). ${ }^{19}$ However, an author's rights remained limited to publication and copying. ${ }^{20}$ Courts did not recognize derivative rights ${ }^{21}$ as a distinct entity, instead generally construing the scope of protection quite narrowly. ${ }^{22}$ For example, in Stowe v. Thomas, Harriet Beecher Stowe unsuccessfully argued that a German translation of Uncle Tom's Cabin ${ }^{23}$

${ }^{15}$ Act of May 31, 1790, ch. 15, § 1, 1 Stat. 124, 124 (repealed 1831).

${ }^{16} I d$.

${ }^{17}$ U.S. CONST. art. I, § 8, cl. 8.

${ }^{18}$ See Tyler T. Ochoa \& Mark Rose, The Anti-Monopoly Origins of the Patent and Copyright Clause, 84 J. PAT. \& TRADEMARK OfF. SOC'Y 909, 922-28 (2002) (describing the Framers' concerns regarding intellectual property monopolies). Indeed, Thomas Jefferson explicitly suggested that the Bill of Rights provide "clearly and without the aid of sophisms for ... [a] restriction against monopolies." Letter from Thomas Jefferson to James Madison (Dec. 20, 1787), in 1 THE REPUBlic OF LETTERS: THE CORRESPONDENCE BETWEEN THOMAS JEFFERSON AND JAMES MADISON, 1776-1826, at 512 (James Morton Smith ed., 1995).

${ }_{19}$ Act of Feb. 3, 1831, ch. 16, $\S \S 1-2,4$ Stat. 436, 436 (repealed 1870).

${ }^{20} I d . \S 1$.

${ }^{21}$ In other words, courts did not recognize the right to transform copyrighted material into a new work, such as making a postcard featuring a painting, a movie based on a play, or a sequel to a novel.

${ }^{22}$ See Amy B. Cohen, When Does a Work Infringe the Derivative Works Right of a Copyright Owner?, 17 CARDOZO ARTS \& ENT. L.J. 623, 626 (1999) ("Even when musical compositions were added to the list of protectable works in 1831, the author of such works was not given a right to control performances of those works ....").

${ }^{23}$ HARriet BeEcher Stowe, UnCle Tom's CABIN (Univ. of Va. Library) (1852). 
infringed her copyright in the novel. ${ }^{24}$ The court, reasoning that copyright protection only applied to literal, word-for-word copying, rejected Stowe's infringement claims, holding that "[a] translation may, in loose phraseology, be called a transcript or copy of her thought or conceptions, but in no correct sense can it be called a copy of her book. ${ }^{25}$

However, in the latter half of the nineteenth century, Congress began to grant authors certain limited rights in derivative works. ${ }^{26}$ In 1856, copyright holders were given the "sole right to act, perform, or represent [their original work of authorship], or cause it be acted, performed, or represented, on any stage or public place." ${ }^{27}$ This "public performance" right was expanded in an 1870 statute that allowed "authors [to] reserve the right to dramatize or translate their own works." 28

Complementing this increase in protection afforded to authors was a judicial recognition of what has come to be known as the first sale doctrine. According to this principle, an author's interest in her intellectual property is distinct from consumers' personal property rights in legitimately purchased items containing the author's creative expression. ${ }^{29}$ Following steady approval by the lower federal courts, ${ }^{30}$

2423 F. Cas. 201 (C.C.E.D. Pa. 1853) (No. 13,514).

${ }^{25} I d$. at 208

${ }^{26}$ See Cohen, supra note 22, at 627 (discussing Congress's gradual expansion of the scope of copyright protection).

${ }^{27}$ Act of Aug. 18, 1856, ch. 169, 11 Stat. 138, 139 (repealed 1870).

${ }^{28}$ Act of July 8, 1870, ch. 230, § 86, 16 Stat. 198, 212 (repealed 1909). The reservation requirement was subsequently dropped, and the dramatization right became automatic in 1891. Act of Mar. 3, 1891, ch. 565, § 1, 26 Stat. 1106, 1107 (repealed 1909).

${ }^{29}$ See Cohen, supra note 22, at 629-31 (discussing the first sale doctrine). For modern glosses on the topic, see Quality King Distribs., Inc. v. L'Anza Research Int'l, Inc., 523 U.S. 135, 146-51 (1998) (applying the first sale doctrine to imported copies of protected works); R. Anthony Reese, The First Sale Doctrine in the Era of Digital Networks, 44 B.C. L. REV. 577, 578, 610-15 (2003) (examining the impact of technological change on the first sale doctrine).

${ }^{30}$ See, e.g., Kipling v. G.P. Putnam's Sons, 120 F. 631, 634 (2d Cir. 1903) (holding that the defendants did not commit copyright infringement by selling a set of the plaintiff's works that they purchased from him, even though a previous compilation of the plaintiff's works had already been copyrighted by a different publisher); Doan v. Am. Book Co., 105 F. 772, 776 (7th Cir. 1901) (concluding that the appellant did not infringe upon the appellee's copyright because " $[\mathrm{t}]$ he sale of [the copyrighted books] by the appellee carried with it the ordinary incidents of ownership in personal property ... and the appellants, purchasing them, had the right to resell them"); Harrison v. Maynard, Merrill \& Co., 61 F. 689, 691 (2d Cir. 1894) ("[T]he right to restrain the sale of a particular copy of [a] book ... has gone when the owner of the copyright and 
the Supreme Court formally endorsed the first sale doctrine in BobbsMerrill Co. v. Straus, holding that the sole right to "vend" a work protected by copyright law extended only to the initial sale of any embodiment of an intellectual property; thus " $[\mathrm{t}]$ he purchaser of a book, once sold by authority of the owner of the copyright, may sell it again, although he could not publish a new edition of it."

In addition to these rights in tangible property, courts in the midnineteenth century also began to hold that certain types of copying and borrowing were not violations of an author's exclusive rights. In Folsom v. Marsh, Justice Story first articulated the principle (later to become the fair use doctrine) that "a fair and bona fide abridgment of the [copyrighted] work" might not be deemed an impermissible infringement. ${ }^{32}$ As the name implies, the fair use doctrine is grounded in the equitable notion that certain forms of appropriation-for example, copying portions of a protected work in order to criticize or parody it—are inherently reasonable. While an author may not like having her creative expression lampooned, a parodic work generally does not act as a market substitute for the original. ${ }^{33}$ Some scholars have suggested that the fair use doctrine arose to address the sorts of uses where an author is most likely to be unwilling to license her work

of that copy has parted with all his title to it, and has conferred an absolute title to the copy upon a purchaser...."); Clemens v. Estes, 22 F. 899, 900 (C.C.D. Mass. 1885) (holding that the defendants "had a right to buy, or contract to buy, books from agents who lawfully obtained them by purchase from the plaintiff or his publishers"); Stowe, 23 F. Cas. at 206-07 ("When [an author] has sold his book, the only property which he reserves to himself, or which the law gives to him, is the exclusive right to multiply the copies of that particular combination of characters which exhibits to the eyes of another the ideas intended to be conveyed.").

${ }^{31} 210$ U.S. 339, 350 (1908).

329 F. Cas. 342, 349 (C.C.D. Mass. 1841) (No. 4901) (Story, Circuit Justice). Despite the fact that Justice Story suggested the possibility of a fair use defense, the defendant in Folsom, who had reprinted letters written by George Washington that were first published by the plaintiff, was nevertheless found to have borrowed too much from the plaintiff's work. Id. Interestingly, part of Justice Story's opinion was grounded in a labor/misappropriation rationale, noting that if "the labors of the original author are substantially to an injurious extent appropriated by another, that is sufficient, in point of law, to constitute a piracy pro tanto.” Id. at 348. Nevertheless, Justice Story's framework in Folsom formed the basis for subsequent fair use analyses and remained to a significant degree unchanged as it was ultimately codified by Congress. See Michael J. Madison, A Pattern-Oriented Approach to Fair Use, 45 WM. \& MARY L. REV. 1525, 1588 (2004) (describing the development of the fair use doctrine); see also infra note 55 and accompanying text (discussing the codification of fair use).

${ }^{33}$ By contrast, bootleg DVDs and CDs are examples of market substitutes that prevent authors from capturing the full market value of their works. 
for a reasonable fee (such as a criticism and parody). ${ }^{34}$ Others (including, recently, the Supreme Court) have suggested that fair use may be required by the First Amendment. ${ }^{35}$

Whatever the rationale, the judicially created doctrines of first sale and fair use stand out against the general trend of affording copyright holders increased protection. Moreover, they share a recognition that certain rights ought to vest in persons other than the author of a copyrighted work.

Another notable limitation on authors emerged in the late nineteenth century: the Supreme Court, in Baker v. Selden, held that facts and ideas were uncopyrightable. ${ }^{36}$ The Court established the idea/ expression dichotomy, holding that while an author's original expression of an idea is protectable, the underlying idea itself is "the common property of the whole world." ${ }^{37}$ Despite a general trend towards increasing the types of works that could be protected by copyright, ${ }^{38}$ the Court here announced a clear restriction on copyrightable subject matter. This again reflects the notion that certain aspects of intellectual property become part of the public domain immediately, rather than at the expiration of a copyright's term.

In 1905, President Theodore Roosevelt called on Congress to completely overhaul the copyright system from the ground up, noting that the patchwork development of the scheme through statutory amendments and judicial decisions had produced a confusing and inconsistent system that burdened artists without providing any comparable benefit to the public and that failed to address the many technological advancements that had, by that time, allowed for the

${ }^{34}$ See, e.g., Wendy J. Gordon, Fair Use as Market Failure: A Structural and Economic Analysis of the Betamax Case and Its Predecessors, 82 CoLum. L. REV. 1600, 1614 (1982) ("Fair use is one label courts use when they approve a user's departure from the market.”).

${ }^{35}$ See, e.g., Eldred v. Ashcroft, 537 U.S. 186, 219 (2003) (noting that copyright law "incorporates... speech-protective purposes and safeguards" and "contains built-in First Amendment accommodations"); see also Neil Weinstock Netanel, Locating Copyright Within the First Amendment Skein, 54 STAN. L. REV. 1, 20-23 (2001) (discussing the relationship between fair use and the First Amendment).

${ }^{36} 101$ U.S. 99, 100-01 (1879) (holding that "truths of a science" and "methods of an art" cannot be protected by copyright).

${ }^{37} I d$. at 100.

${ }^{38}$ See, e.g., Burrow-Giles Lithographic Co. v. Sarony, 111 U.S. 53, $60-61$ (1884) (holding that photographs are entitled to copyright protection). 
production of new types of creative works. ${ }^{39}$ Congress responded by passing the Copyright Act of 1909 (the 1909 Act). ${ }^{40}$ With the Act, Congress once again expanded the subject matter of copyrightable works, this time to include "all the writings of an author." ${ }^{41}$ The Act also eliminated the requirement that works be registered before receiving protection. Following the passage of the Act, all works affixed with a copyright notice were protected immediately upon publication. $^{42}$ Congress also responded to judicial trends in the field, formally codifying the first sale doctrine. ${ }^{43}$ And, once again, Congress extended the duration of protection, providing for an initial term of twenty-eight years followed by a renewal term of an additional twentyeight years. $^{44}$

Several notable expansions in the area of copyrightable subject matter followed the passage of the 1909 Act. In 1912, Congress brought motion pictures within the ambit of copyright protection $;^{45}$ in 1952, protection was extended to for-profit public performances of nondramatic literary works; ${ }^{46}$ and although during this time Congress

${ }^{39}$ As President Theodore Roosevelt told Congress:

Our Copyright laws urgently need revision. They are imperfect in definition, confused and inconsistent in expression; they omit provision for many articles which, under modern reproductive processes, are entitled to protection; they impose hardships upon the copyright proprietor which are not essential to the fair protection of the public; they are difficult for the courts to interpret and impossible for the Copyright Office to administer with satisfaction to the public. Attempts to improve them by amendment have been frequent, no less than twelve acts for the purpose having been passed since the Revised Statutes. To perfect them by further amendment seems impractical. A complete revision of them is essential.

Message of President Theodore Roosevelt to Congress (Dec. 1905), reprinted in ALAN LATMAN ET AL., COPYRIGHT FOR THE EIGHTIES 7 (1985).

${ }^{40}$ Act of Mar. 4, 1909, ch. 320, 35 Stat. 1075 (amending and consolidating the existing legislation on copyright law) (repealed 1976).

${ }^{41} I d . \S 4$.

${ }^{42}$ See id. $\$ 10$ (stating that compliance with the provisions of the Act would ensure protection)

${ }^{43}$ See id. $\$ 41$ (providing that a copyright is "distinct from the property in the material object copyrighted, and the sale or conveyance, by gift or otherwise, of the material object shall not of itself constitute a transfer of the copyright").

${ }^{44} I d . \S 23$.

45 See Act of Aug. 24, 1912, ch. 356, 37 Stat. 488, 488 (amending the copyright statute to include protection for "[m] otion-picture photoplays" and "[m] otion pictures other than photoplays") (repealed 1976).

${ }^{46}$ See Act of July 17, 1952, Pub. L. No. 82-575, 66 Stat. 752, 752 (amending the copyright statute to grant copyright holders the right to "present the copyrighted work in public for profit if it be a lecture, sermon, address or similar production, or other nondramatic literary work") (repealed 1976). 
declined to conform U.S. copyright law to the 1886 Berne Convention (which sought to harmonize international copyright standards), ${ }^{47}$ it did relax the restrictions preventing foreign works from receiving domestic copyright protection. ${ }^{48}$

Yet judges again tempered these expansions with further recognition that some content was beyond protection. In 1942, a federal district court held that certain aspects of storytelling were scénes à faire-features so generic that they were uncopyrightable. ${ }^{49}$ Modern courts commonly define 'scénes à faire' as "incidents, characters or settings which are as a practical matter indispensable, or at least standard, in the treatment of a given topic. ${ }^{, 50}$ This doctrine again reflects the notion that the most crucial building blocks for future creative works fall outside the scope of copyright protection.

The most recent overhaul of United States copyright law occurred in 1976, with the passage of the Copyright Act of 1976 (the 1976 Act). ${ }^{51}$ Congress continued its trend of expanding copyright protection to an ever-broader array of subject matter: "[c] opyright protection subsists ... in original works of authorship fixed in any tangible medium of expression, now known or later developed, from which they can be perceived, reproduced, or otherwise communicated, ei-

${ }^{47}$ Berne Convention for the Protection of Literary and Artistic Works, Sept. 9, 1886, 828 U.N.T.S. 221 (last revised July 24, 1971)[hereinafter Berne Convention]. One major obstacle to U.S. adoption was that the Berne Convention required signatories to provide certain 'moral rights' to authors, in keeping with the European approach to intellectual property, though potentially in conflict with the U.S. Constitution's explicit utilitarian philosophy. Natalie C. Suhl, Note, Moral Rights Protection in the United States Under the Berne Convention: A Fictional Work?, 12 FordHAM INTELL. PROP. MEDIA \& ENT. L.J. 1203, 1212-15 (2002).

${ }^{48}$ See, e.g., Act of June 3, 1949, Pub. L. No. 81-84, 63 Stat. 153 (relaxing the copyright provisions governing foreign works) (repealed 1976); Act of July 3, 1926, ch. 743, 44 Stat. 818 (allowing copyright protection for some works not manufactured within the United States) (repealed 1976).

${ }^{49}$ See Cain v. Universal Pictures Co., 47 F. Supp. 1013, 1017 (S.D. Cal. 1942) (" $[\mathrm{S}]$ imilarities and incidental details necessary to the environment or setting of an action are not the material of which copyrightable originality consists."). Although this was the first case to use the phrase "scénes à faire," judges employed similar reasoning in cases dating back at least as far as 1913. See, e.g., Bachman v. Belasco, 224 F. 815, 816 (S.D.N.Y. 1913) ("It is to be expected that two playwrights working independently from a common source may develop similarities in their plots and in their lines ....").

${ }^{50}$ Alexander v. Haley, 460 F. Supp. 40, 45 (S.D.N.Y. 1978). For a collection of cases using the Alexander v. Haley definition of 'scénes à faire,' see Leslie A. Kurtz, Copyright: The Scenes a Faire Doctrine, 41 FLA. L. REV. 79, 81 n.8 (1989).

${ }^{51}$ See Pub. L. No. 94-553, 90 Stat. 2541 (codified as amended at 17 U.S.C. $§ \S 101-$ 803 (2000)) (revisiting in its entirety the existing law on copyrights). 
ther directly or with the aid of a machine or device." ${ }^{52}$ And yet this was simultaneously tempered with a codification of the idea/expression dichotomy, cordoning off from copyright protection any "idea, procedure, process, system, method of operation, concept, principle, or discovery, regardless of the form in which it is described, explained, illustrated, or embodied in such work." ${ }^{33}$ Similarly, Congress formally extended to copyright owners the exclusive right "to prepare derivative works based upon the copyrighted work," ${ }^{, 4}$ but again tempered this grant with a codification of the fair use doctrine. ${ }^{55}$ Thus, the exclusive right to prepare derivative works did not prevent the public from using any copyrighted material "for purposes such as criticism, comment, news reporting, teaching (including multiple copies for classroom use), scholarship, or research. ${ }^{56}$

The 1976 Act highlights other trends as well. The duration of copyright protection was again extended, replacing the oncerenewable twenty-eight year term with a single term extending for the life of the author plus fifty years. ${ }^{57}$ A sunset provision was added to the manufacturing requirement, ${ }^{58}$ and the publication requirement was replaced with the "fixation" requirement (granting protection to any work of authorship "fixed in any tangible medium of expression"). ${ }^{59}$

The subject matter of copyrights was expanded again in 1980 to include computer software. ${ }^{60}$ In 1988, Congress ostensibly brought U.S. copyright law into compliance with the Berne Convention, via The Berne Convention Implementation Act. ${ }^{61}$ In 1990, Congress en-

${ }^{52} I d . \S 102(\mathrm{a})$.

${ }^{53} I d . \S 102(\mathrm{~b})$.

${ }^{54} I d . \S 106(2)$.

${ }^{55}$ See id. $\S 107$ (providing the concept of fair use as a defense to copyright infringement).

${ }^{56} \mathrm{Id}$.

${ }^{57} I d . \S 302(\mathrm{a})$. Works for hire, as well as anonymous and pseudonymous works, were awarded protection for a term of seventy-five years from publication or onehundred years from creation, whichever was shorter. Id. §302(c).

${ }^{58}$ Id. $\S 601$.

${ }^{59} I d . \S 102(\mathrm{a})$.

${ }^{60}$ Act of Dec. 12, 1980, Pub. L. No. 96-517, § 10, 94 Stat. 3015, 3028-29.

${ }^{61}$ Pub. L. No. 100-568, § 2, 102 Stat. 2853 (1988) (codified as amended at 17 U.S.C. $\S 101)$. While the Act removed the formal affixation requirement, it did not create any new 'moral rights' rights for artists, but rather asserted that existing U.S. law already provided sufficient protection to satisfy the Berne requirements. See Suhl, supra note 47, at 1212-13 (discussing the Berne Convention Implementation Act). 
acted the Visual Artists Rights Act (VARA), ${ }^{62}$ which provided certain additional 'moral rights' to the creators of "work[s] of visual art." ${ }^{, 63}$ In 1998, Congress passed the Sonny Bono Copyright Term Extension Act (CTEA) ${ }^{64}$ which extended the term of copyright protection for an additional twenty years, ${ }^{65}$ as well as the Digital Millennium Copyright Act (DMCA), ${ }^{66}$ which barred the circumvention of any "technological measure that effectively controls access to a [copyright-protected] work." ${ }^{67}$

Also during this time, there were several notable Supreme Court cases that clarified the scope of the fair use doctrine. In Sony Corp. of America v. Universal City Studios, Inc., the Court expanded the doctrine to include the "time-shifting" use of VCRs. ${ }^{68}$ In Harper $\mathcal{E}$ Row Publishers, Inc. v. Nation Enterprises, the Court held that fair use did not extend to the publication of substantial excerpts from a forthcoming work. ${ }^{69}$ And in Campbell v. Acuff-Rose Music, Inc., the Court strongly reaffirmed the principle that fair use covers parody. ${ }^{70}$

The point of the preceding analysis is not merely to establish the current state of copyright law; rather, it is to suggest that copyright protection is evolving in a predictable, determinable pattern.

Copyrightable subject matter has grown from a brief list of qualifying art forms in 1790 (maps, charts, and books) to include both contemporary media that were already known at the time of the framing,

${ }^{62}$ Pub. L. No. 101-650, tit. VI, 104 Stat. 5128 (1990).

${ }^{63} I d$. $\$ 603$. Because of VARA's narrow definition of "work of visual art," these rights are rarely litigated. See Suhl, supra note 47, at 1215 (noting that the statute is "invoked only in very limited circumstances").

${ }^{64}$ Pub. L. No. 105-298, 112 Stat. 2827 (1998).

${ }^{65}$ Id. $\S 102$. The Supreme Court held that this did not violate the "limited Times" constraint, even as applied to pre-existing works. Eldred v. Ashcroft, 537 U.S. 186, 194 (2003). For further discussion of Eldred, see infra notes 155-56 and accompanying text.

${ }^{66}$ Pub. L. No. 105-304, 112 Stat. 2860 (1998) (codified in part at 17 U.S.C. $\S \S$ 1201-1205 (2000)). For contrasting views of the legislation, compare Electronic Frontier Foundation, Unintended Consequences: Five Years Under the DMCA (2003), http://www.eff.org/IP/DMCA/unintended_consequences.pdf (criticizing the DMCA for its chilling effect on free expression, its jeopardization of fair use rights, its imposition on competition and innovation, and its overbroad ban on legitimate computer activities), with Orin S. Kerr, A Lukewarm Defense of the Digital Millennium Copyright Act in COPY Fights: THE FUTURE OF INTELlectuAl PROPERTY IN THE INFORMATION AGE 163 (Adam Thierer \& Wayne Crews eds., 2002) (defending the DMCA).

${ }^{67} 17$ U.S.C. $\$ 1201$ (a) (2000).

68464 U.S. 417, 421 (1984). "Time-shifting" refers to recording a program as it is broadcast and watching it at a later time.

${ }^{69} 471$ U.S. 539, 542 (1985).

${ }^{70} 510$ U.S. 569, 578-85 (1994). 
as well as later-developed media such as photographs, motion pictures, and computer software; and the current broadly worded statute allows protection for any manner of creative expression capable of being fixed in a tangible medium. Although several states have extended copyright protection to unfixed works, ${ }^{71}$ federal expansion in this area seems unlikely. ${ }^{72}$ However, it seems quite probable that the subject-matter limitation will continue evolving to reflect an everbroader understanding of what may constitute an original work of authorship. ${ }^{73}$

The scope of copyright protection awarded to authors has similarly expanded from narrow publication and copying rights to include broad coverage of derivative works. The institutional hurdles required to secure protection have decreased dramatically. ${ }^{74}$ And the duration of protection has grown from a renewable fourteen-year term to the life of the author plus seventy years. ${ }^{75}$

Although these trends might suggest that the copyright universe is expanding indefinitely, the limiting rules—such as the doctrines of fair use, scénes à faire, and first sale, as well as the idea/expression dichotomy—all suggest a tipping point, after which the public's interest

${ }^{71}$ See, e.g., Cal. Civ. Code $\$ 980$ (a) (1) (West Supp. 2005) (expanding copyright protection to include works that are not fixed in a tangible medium of expression).

${ }^{72}$ Some scholars have suggested that fixation is not merely "a traditional requirement for federal statutory copyright protection" but is in fact "a constitutional requirement inherent in the Copyright Clause's use of the word 'Writings' to describe the subject matter that Congress can protect pursuant to the Clause." Thomas B. Nachbar, Intellectual Property and Constitutional Norms, 104 COLUM. L. REV. 272, 285 (2004); see also Joseph C. Merschman, Note, Anchoring Copyright Laws in the Copyright Clause: Halting the Commerce Clause End Run Around Limits on Congress's Copyright Power, 34 CONN. L. REV. 661, 677-92 (2002) (arguing that fixation is a constitutional requirement). The Eleventh Circuit in United States v. Moghadam accepted this premise arguendo but decided the case on other grounds. 175 F.3d 1269, 1277 (1999).

Although the issue has not been brought squarely before the Supreme Court, in a pre-1976 Act case the Court did suggest that a physical embodiment was required. See Goldstein v. California, 412 U.S. 546, 561 (1973) ("[A]lthough the word 'writings' might be limited to script or printed material, it may be interpreted to include any physical rendering of the fruits of creative intellectual or aesthetic labor.").

${ }^{73}$ For example, a district court recently held that copyright protection would be available to a "sufficiently creative" sequence of yoga asanas. Open Source Yogan Unity v. Choudhury, No. C 03-3182 PJH, 2005 WL 756558, at*4 (N.D. Cal. Apr. 1, 2005).

${ }^{74}$ See Christopher Sprigman, Reform(aliz)ing Copyright, 57 STAN. L. REV. 485, 494-95 (2004) (discussing the transition from a conditional copyright regime to an unconditional copyright regime).

${ }^{75}$ Compare Act of May 31, 1790, ch. 15, § 1, 1 Stat. 124, 124 (renewable fourteenyear terms), with 17 U.S.C. $\$ 302$ (a) (2000) (life of the author plus seventy years). 
becomes supreme. However, while all of these doctrines serve to limit the outer bounds of exclusive rights awarded to authors, none of them act to resist the continual lengthening of copyright duration, and thus this trend seems likely to continue. Moreover, the recognition that certain aspects of a work should vest in the public domain immediately upon its creation only reinforces the intuition that those rights that do not immediately vest are ones that society can afford to protect with copyright indefinitely.

\section{FOREVER AND A DAY: INDEFINITELY RENEWABLE COPYRIGHT}

Building on the conclusion in Part I that the duration of copyright protection is likely to continue expanding, this Part examines the merits of advancing this pattern to its ultimate end and adopting a regime that would permit perpetual copyright protection.

Scholars have posited numerous justifications for creating property rights in intellectual goods. A Lockean approach suggests that authors should be rewarded for the fruits of their labor. ${ }^{76}$ HegelianPersonhood theory argues that individuals achieve self-actualization through their creative works and thus should have certain 'moral rights' in their works even after creation. ${ }^{77}$ Professor Neil Netanel has argued that copyright protection serves a structural function in a democratic society, ensuring the independence of authors and publishers and thereby establishing an important check on the ability of the government to control the content and flow of information. ${ }^{78}$

${ }^{76}$ See Alfred C. Yen, Restoring the Natural Law: Copyright as Labor and Possession, 51 OHIO ST. L.J. 517, 523-24 (1990) ("Since people owned their bodies, Locke reasoned that they also owned the labor of their bodies and, by extension, the fruits of that labor." (footnote omitted)).

77 See Margaret Jane Radin, Contested Commodities 34 (1996) (noting that for Kant and Hegel, "only objects separate from the self are suitable for alienation"); Margaret Jane Radin, Property and Personhood, 34 STAN. L. REV. 957, 971-72 (1982) (arguing that property affects an individual's personhood, and therefore rights should be maintained over property); see also G.W.F. HEGEL, PHILOSOPHY OF RIGHT $§ 66$ (T.M. Knox trans., Oxford Univ. Press 1952) (1821) (“[T]hose goods, or rather substantive characteristics, which constitute my own private personality and the universal essence of my self-consciousness are inalienable and my right to them is imprescriptible. Such characteristics are my personality as such, my universal freedom of will, my ethical life, my religion."). This theory is closely aligned with the European approach of providing 'moral rights' to authors. Suhl, supra note 47, at 1208-11.

${ }^{78}$ See Neil Weinstock Netanel, Copyright and a Democratic Civil Society, 106 YALE L.J. 283, 352-53 (1996) ("By supporting a market-based sector of authors and publishers, copyright achieves considerable independence from government administrators and private patrons who would otherwise meddle in expressive content."). 
Absent any constitutional limitation, Congress might seek to regulate copyright in order to pursue any one of these philosophical ends. However, among all the powers granted to Congress in Section 8 of Article I, the Intellectual Property Clause is unique in that it provides not just a power (in this case, the ability to grant copyrights and patents) but also a particular philosophical rationale (and thus a possible constraint upon Congress's use of that power): "[t]o promote the Progress of Science and useful Arts." ${ }^{\text {"79 }}$ As a result, legislation enacted pursuant to the Intellectual Property Clause is generally analyzed solely from a consequentialist perspective: does it provide a sufficient incentive for authors to create new works, and does it provide the public with appropriate access to those works? ${ }^{80}$ However, these inquiries are often limited by a presupposition that the utilitarian goals expressed in the Promote Progress Clause can only be achieved through a limited term of protection that must inevitably result in all works ultimately passing into the public domain.

Professor William Landes and Judge Richard Posner have proposed a countervailing model that would allow copyrighted works to remain protected indefinitely. ${ }^{81}$ Although indefinite protection could be realized in numerous forms, their suggested framework would involve the reinstitution of formal requirements for copyright registration and renewal, with no set limit on the number of times an author and her heirs or assignees could renew the copyright in the work. ${ }^{82}$ This Part argues that the adoption of an indefinitely renewable copyright scheme would present numerous advantages over the current framework, and moreover is preferable to the current practice of extending the copyright term every time the oldest protected works are about to expire.

Unlike the other changes to copyright law proposed in this Comment, the reintroduction of formal requirements would represent a

${ }^{79}$ U.S. CONST. art. I, $\$ 8$, cl. 8.

${ }^{80}$ See Stephen Breyer, The Uneasy Case for Copyright: A Study of Copyright in Books, Photocopies, and Computer Programs, 84 HARV. L. REV. 281, 282 (1970) (discussing these ends as the twin goals of copyright law); see also Twentieth Century Music Corp. v. Aiken, 422 U.S. 151, 156 (1975) ("Creative work is to be encouraged and rewarded, but private motivation must ultimately serve the cause of promoting broad public availability of literature, music, and the other arts.”); Fox Film Corp. v. Doyal, 286 U.S. 123, 127 (1932) ("The sole interest of the United States and the primary object in conferring the monopoly lie in the general benefits derived by the public from the labors of authors.").

${ }^{81}$ William M. Landes \& Richard A. Posner, Indefinitely Renewable Copyright, 70 U. CHI. L. REV. 471, 473 (2003)

${ }^{82} I d$. 
clear shift in the opposite direction of copyright law's current trajectory. ${ }^{83}$ However, these requirements would serve several important functions and would mitigate or eliminate many of the prime concerns generally raised in opposition to extended or perpetual terms of copyright protection.

First, the reintroduction of registration and renewal would reduce the tracing costs inherent in identifying the owner (or owners) of a copyright in a given work. ${ }^{84}$ This is not generally a problem associated with recently published commercial works (as most content owners and distributors include copyright notices even though such affixation is no longer required for copyright protection) ${ }^{85}$ however, tracing costs are often cited as a reason not to extend the term of copyright protection, ${ }^{86}$ based on the rationale that a longer term increases the possibility that a copyrighted work will be "orphaned." ${ }^{87}$ While this may be true in the case of automatic extensions, ${ }^{88}$ requiring reasonably frequent renewal (for example, every ten or twenty years) would

${ }^{83}$ See supra note 74 and accompanying text (noting that copyright law has evolved in the direction of reducing and eliminating formalities).

${ }^{84}$ Landes \& Posner, supra note 81, at 477-78; see also LESSIG, supra note 2, at 288 ("Today, there is no simple way to know who owns what, or with whom one must deal in order to use or build upon the creative work of others. . . [T] hus, the lack of formalities forces many into silence where they otherwise could speak.").

${ }^{85}$ See Berne Convention Implementation Act, Pub. L. No. 100-568, § 7, 102 Stat. 2853 (1988) (codified as amended at 17 U.S.C. $\$ \S 401-406$ (2000)) (modifying the copyright scheme to make the affixation of copyright notice permissive rather than required).

${ }^{86}$ See, e.g., Hearings on S. 483 Before the S. Comm. on the Judiciary, 104th Cong. 26 (1997) (testimony of Larry Urbanski, Chairman, American Film Heritage Association) [hereinafter Urbanski Senate Testimony] (arguing that an increased term of protection will increase the difficulty in preserving old films due to increased tracing costs).

87 "Orphan works" are generally defined as "copyrighted works where the rights holder is hard to find." Save Orphan Works, http://eldred.cc (last visited Jan. 20, 2006). These works present a problem for follow-on artists who wish to use them, since the search costs associated with identifying copyright owners make the endeavor prohibitively expensive, "even when [the artist would] be willing to pay [a reasonable license fee] to use them. In many cases the works were abandoned because they no longer produced any income. In most cases, rights holders, once found, are delighted to have their work used." Id.

One area where the problem has been particularly pronounced is film preservation, as many early films were produced by studios that are now defunct. See Urbanski Senate Testimony, supra note 86, at 26.

The Copyright Office recently requested public comments for a study of orphan works. Orphan Works, 70 Fed. Reg. 3739 (Jan. 26, 2005).

${ }^{88}$ E.g., Sonny Bono Copyright Term Extension Act, Pub. L. No. 105-298, 112 Stat. 2827 (1998) (automatically extending the term of copyright protection by twenty years). 
actually reduce the tracing costs associated with the current life-plusseventy years term of protection. ${ }^{89}$

Similarly, a transition from the current system to one that requires renewal at regular intervals would likely lead to a large number of works actually entering the public domain sooner. ${ }^{90}$ While critics of copyright extension often complain that it 'starves' the public domain by prolonging the time before works become free for public use, ${ }^{91}$ given the sheer volume of material that potentially qualifies for copyright protection today (from e-mails to doodles to outgoing answering machine messages ${ }^{92}$ ), it seems implausible that any more than a small fraction of these works would be renewed even once. ${ }^{93}$

This intuition is further supported by empirical data examining works created and published prior to the 1976 Act. Of the works registered for copyright protection between 1883 and 1964, only ten percent were renewed at the end of their initial twenty-eight-year term of protection. ${ }^{94}$ Although the cost of renewal may have been a significant deterrent for authors of composite works (such as a large series of individually copyrighted photographs), in the vast majority of cases it appears that the abandonment of copyright protection was due to the "sheer bother of applying for renewal" rather than the renewal fee (which grew from fifty cents in 1909 to the still modest $\$ 60$ in 2002). ${ }^{95}$

And yet, while the bulk of copyrighted works would eventually enter into the public domain, it remains a near certainty that the most popular and valuable works would be renewed so long as they remained commercially viable. ${ }^{96}$ Thus, it is important to focus on the effect of allowing this select subset of works to remain in private control indefinitely. For these works, there are the basic concerns that, as they grow more valuable over time, there would be increasing costs to the public, in both the licensing fees that the copyright holder could

${ }^{89}$ Landes \& Posner, supra note 81 , at 477-78.

${ }^{90} I d$. at $517-18$.

${ }^{91}$ See, e.g., LESSIG, supra note 2, at 24-25.

92 These all could qualify for copyright protection as "original works ... fixed in [a] tangible medium of expression.” 17 U.S.C. $\$ 102$ (a) (2000).

93 See Landes \& Posner, supra note 81, at 474 (arguing, based on empirical data, that even under a regime in which copyrights could be renewed indefinitely, "few would be renewed if even a slight fee were required," and only "the most valuable works would probably be renewed many times").

${ }^{9} I d$. at $496-500$.

${ }^{95}$ Id. at 474 \& n. 10 .

${ }^{96}$ See id. at 473-74 (discussing data on the number of copyrights that have been renewed). 
charge as well as the deadweight loss attributable to individuals being unwilling or unable to pay the increased fees. ${ }^{97}$ Yet these problems will persist in the current system as well, so long as Congress continues in its trend of retroactively extending copyright protection.

Moreover, it is important to consider whether there may be a net gain from allowing these works to be renewed indefinitely. Certainly, from a Lockean perspective, such a change would represent an improvement; ${ }^{98}$ but might there be a utilitarian gain as well?

The notion that copyright protection ought to have an expiration date is grounded in traditional monopoly concerns, ${ }^{99}$ leading many scholars to assume that economic efficiency requires all copyrights to be limited in duration. ${ }^{100}$ While this assumption is at odds with traditional economic notions that valuable resources should be owned in order to ensure "efficient exploitation and to avoid overuse," not self-evident that these monopoly concerns apply with equal force to intangible "intellectual" goods.

Indeed, at first blush, intellectual property might seem to be immune to such concerns: the non-rival, non-extinguishable nature of creative expression would seem to suggest that once in the public domain, a work could be exploited by any member of society in whatever way she believed would maximize her own private value, without any negative externalities. ${ }^{102}$

${ }^{97} I d$. at $479-81$.

${ }^{98}$ See supra note 76 and accompanying text (discussing the Labor Theory of intellectual property ownership).

${ }_{99}$ See Ochoa \& Rose, supra note 18, at 922-28 (discussing debates over the ratification of the copyright provision of the Constitution and ensuing concerns about monopolies).

${ }^{100}$ See Landes \& Posner, supra note 81, at 471 (noting that this is a "widely accepted proposition"); see also Brief of George A. Akerlof et al. as Amici Curiae Supporting Petitioners at 10-12, Eldred v. Ashcroft, 537 U.S. 186 (2003) (No. 01-618), 2002 WL 1041846 (arguing that copyright term extension increases the social cost of monopoly); Jon M. Garon, Media E Monopoly in the Information Age: Slowing the Convergence at the Marketplace of Ideas, 17 CARDOZO ARTS \& ENT. L.J. 491, 598 (1999) ("The trend toward greater information ownership and longer copyright terms will drive up the social costs of new work and drive down the opportunity for works built on a shared public experience.").

${ }^{101}$ Landes \& Posner, supra note 81, at 475. See generally Garrett Hardin, The Tragedy of the Commons, 162 SCIENCE 1243, 1244 (1968) ("Ruin is the destination toward which all men rush, each pursuing his own best interest in a society that believes in the freedom of the commons.").

${ }^{102}$ See, e.g., Dennis S. Karjala, Statement of Copyright and Intellectual Property Law Professors in Opposition to H.R. 604, H.R. 2589, and S. 505, "The Copyright Term Extension Act" 9 (Jan. 28, 1998), available at http://homepages.law.asu.edu/ dkarjala/ 
Yet content owners have long recognized that over-exposure reduces the total value of a creative work, and indeed, many copyright holders seeking to maximize their profits do so by carefully restricting their exploitation so as not to saturate and ultimately squander the market for their work. ${ }^{103}$ Similarly, research in behavioral economics suggests that an over-abundance of choices reduces consumer information, making consumers more likely to choose nothing rather than anything. ${ }^{104}$

The point here is not to suggest that there is no value to be had from works in the public domain, but rather that the utilitarian gains from extended copyright protection could easily outweigh the losses. Given the appropriation rights that are immediately available through doctrines such as fair use, the remaining uses of copyrighted works that are withheld from the public are those uses that the public can most easily do without.

Although scholars tend to blanche at the possibility of a world in which Sir Laurence Olivier could not play Hamlet, ${ }^{105}$ such hyperbolic fears are almost certainly overstated. For example, it seems likely that in a world with indefinitely renewable copyright protection, the market for copyright assignments would continue to grow, presumably along the lines of what has already developed in the areas of musical compositions and theatrical works, where large publishing houses such as Samuel French specialize in acquiring and licensing protected works. ${ }^{106}$ Indeed, organizations generally thought of as resource-

OpposingCopyrightExtension/legmats/1998statement.html ("There can be no overgrazing of intellectual property ... because intellectual property is not destroyed or even diminished by consumption. Once a work is created, its intellectual content is infinitely multipliable.").

${ }^{103}$ See, e.g., Bill Britt, Disney's Global Goals, MARKeting, May 17, 1990, at 22 (discussing Disney's efforts to extend the commercial life of its protected properties); see also Landes \& Posner, supra note 81, at 486-88 (demonstrating that congestion or overuse externalities could decrease the total value of an intellectual property).

${ }^{104}$ See, e.g., Christine Jolls, Cass R. Sunstein \& Richard Thaler, A Behavioral Approach to Law and Economics, 50 STAN. L. REV. 1471, 1477-79 (1998) (discussing "bounded rationality").

${ }^{105}$ See, e.g., LESSIG, supra note 2, at 29 (suggesting society is better off with the works of Shakespeare in the public domain).

${ }^{106}$ See generally Samuel French, Inc., Royalties and Rights Information (2004), http://www.samuelfrench.com/store (follow "Royalty Information" hyperlink) (describing performance restrictions and royalty policies for Samuel French plays and musicals). Organizations such as the Copyright Clearance Center have made similar inroads in the information content industry. See, e.g., Copyright Clearance Center, Corporate Overview: Copyright Clearance Solutions (2006), http://www.copyright.com/ 
poor-such as schools and community theaters-are already able to license some protected works because the publishing houses, seeking to capture these smaller markets, employ a licensing structure that allows for price discrimination (based on factors such as theater size and ticket price), making it commercially viable for all involved. ${ }^{107}$

But since it is reasonable to assume that there will be market failures, it is important to consider what will be lost in the cases of works that never enter the public domain and cannot be freely licensed. The public is free to take any underlying ideas from those works (due to the idea/expression dichotomy), as well as to copy as much as is necessary for fair use purposes such as criticism and parody. Thus, the public will lose only those appropriations that fail to meet the thresholds of fair use.

This leads to two logical points: first, the standard for fair use should be clearly defined so as to prevent copyright holders from chilling acceptable expression; ${ }^{108}$ and second, the definition should be broad enough to cover the class of expressions vital to society that would otherwise be suppressed. While this Comment argues that the contours of fair use should be adapted to better fit a regime of indefinitely renewable copyright, even under the current framework, if something fails to meet the minimum standards to qualify for fair use, it should be something that society can do without.

Scholars tend to reject this latter suggestion out of hand, citing (depending on the level of cultural literacy they wish to intimate) either West Side Story ${ }^{109}$ as an adaptation of William Shakespeare's Romeo and Juliet, ${ }^{110}$ or Clueless ${ }^{111}$ as an adaptation of Jane Austen's Emma ${ }^{112}$ as

$\mathrm{ccc} / \mathrm{do} /$ viewPage?pageCode=aul (describing the company's role as an "intermediary between copyright owners and content users").

${ }^{107}$ This is not to say that there are not sometimes troubling conflicts within the system. There is certainly a prevalent perception that the "best" copyrighted works remain too expensive for resource-poor organizations to license. And reduced-fee licensees are often forced to accept strict restrictions. For an example from across the pond that could plausibly happen stateside, see Tom Morgan, Why Grease Is Not the Word, DAILY EXPRESS (U.K.), Nov. 30, 2004, at 26 (describing a school production of Grease that was not allowed to advertise for fear of competing with a professional touring version).

${ }^{108}$ This first point does not seem controversial, though it seems likely to play an important role in establishing a regime of indefinitely renewable copyright. See infra notes 151-53 and accompanying text (arguing that clarification of the fair use Doctrine would address the primary concern regarding indefinitely renewable copyright).

${ }^{109}$ LEONARD BERNSTEIN, WEST SIDE STORY (1957).

${ }^{110}$ William Shakespeare, The Most Excellent and Lamentable Tragedy of RomeO AND Juliet. For a description of West Side Story as "a modern update" of Romeo 
examples of works that would be lost under an indefinitely renewable paradigm. Bracketing for a moment the question of whether or not those expressions should qualify as derivative works infringing the original copyright, ${ }^{113}$ the larger point is that, to the extent copyright protection forces artists to be more creative in order to avoid infringement, the public has benefited. This depends in large part on the idea/expression dichotomy; while the actual expression"Wherefore art thou Romeo?" — - is protected, the underlying ideastar-crossed lovers, things end badly-is immediately vested in the public domain and free for appropriation. Thus, if Shakespeare's works were still under copyright protection, follow-on artists would be free to rely on Shakespeare's words and structure as inspiration, yet they would be forced to add enough unique material or otherwise substantially modify any portions they borrowed ${ }^{115}$ in order to create a non-infringing work, with the marketplace rewarding the most successful innovations.

However, even assuming that the public can appropriately exploit the most valuable copyrighted works (through fair use and the idea/expression dichotomy), there remains the second half of the question: would an indefinitely renewable copyright regime produce a net benefit over the current system? There is, of course, a natural inclination to be skeptical of a framework that would appear to represent a windfall to the holders of those copyrights with lasting value; does the public receive any comparable benefit from the Walt Disney

and Juliet, see Broadway: The American Musical, Memorable Musicals, http://www.pbs.org/wnet/broadway/musicals/westside.html.

${ }^{111}$ CLueless (Paramount Pictures 1995).

${ }^{112}$ Jane Austen, Emma (R.W. Chapman ed., Oxford Univ. Press 1933) (1816). For a discussion of the influence of Emma on the director of Clueless, see Interview by the American Film Institute with Amy Heckerling, Director of Clueless, in Los Angeles, Cal. (Sept. 14, 1995), http://www.jasa.net.au/study/ahinterview.htm.

${ }^{113}$ See infra note 146 and accompanying text (suggesting that under a narrow definition of derivative work, West Side Story and Clueless would not be considered infringements).

${ }_{114}$ SHAKESPEARE, supra note 110 , act 2, sc. 2.

${ }^{115}$ To the extent that certain dramatic schemata are required in order to tell a story, the scénes à faire doctrine holds that such takings do not constitute infringement. See, e.g., Hoehling v. Universal City Studios, Inc., 618 F.2d 972, 979 (2d Cir. 1980) (finding that representations of the Hindenburg disaster did not constitute infringement, as similarities in portrayal were determined by the subject matter); see also supra notes 49-50 and accompanying text (discussing the scénes à faire doctrine). 
Corporation's continued ownership of rudimentary cartoons Walt Disney made almost eighty years ago ${ }^{116}$

The answer may be yes. Beyond simply fostering a higher threshold of creativity for follow-on artists, indefinitely renewable protection encourages copyright owners to promote, enhance, restore, and otherwise commercially exploit their protected works. For example, the film It's a Wonderful Life ${ }^{117}$ fell into the public domain after the expiration of its initial term of protection because "the copyright holder failed to file a timely renewal application." ${ }^{118}$ As a result, there was no quality control over the work: television stations severely edited the film to make room for more commercials, and the broadcast picture quality was poor because no one was willing to invest in restoring the prints. ${ }^{119}$ Moreover, consumers who purchased home video cassettes of the film often unwittingly received low-quality bootlegs. ${ }^{120}$

However, the copyright holders were able to reclaim the film from the public domain by asserting their rights to the underlying short story and music. ${ }^{121}$ Subsequently, the copyright holders invested significant capital in producing a high-quality restoration of the film; this was possible because the investment costs could be recouped through the sale of exclusive distribution rights. ${ }^{122}$ Thus, in at least some circumstances, the public as a whole would seem to derive certain benefits from the extension of private copyright ownership.

As a corollary to these issues related to indefinitely renewable copyright, Congress would likely be able to generate a significant amount of revenue by switching from the current system to one in which copyright owners must pay a set fee for each renewal of their copyright. Indeed, since there is generally a polarization in the value of protected material over time (with most works tending towards ei-

${ }^{116}$ E.g., Plane Crazy (Walt Disney Pictures 1928) (featuring the first appearance of Mickey Mouse); STEAmboat Willie (Walt Disney Pictures 1928) (featuring the first appearance of Mickey Mouse with synchronized sound). While Walt Disney provided Mickey Mouse's voice and personality, the character was actually designed and animated by Ub Iwerks. LESLIE IWERKS \& JOHN KENWORTHY, THE HAND BEHIND THE MOUSE 53-56 (2001).

${ }^{117}$ IT'S A WONDERFUL LIFE (Liberty Films Inc. 1946).

${ }^{118}$ Scott M. Martin, The Mythology of the Public Domain: Exploring the Myths Behind Attacks on the Duration of Copyright Protection, 36 LOY. L.A. L. REV. 253, 273 (2002).

${ }^{119} I d$.

${ }^{120} I d$. at 273-74.

121 Id. at 273.

${ }^{122}$ Id. at 274. 
ther extremely high or extremely low value ${ }^{123}$ ), Congress would be able to charge substantial fees for subsequent renewals without significantly altering the incentive structure created by an indefinitely renewable copyright regime. ${ }^{124}$

What, then, to do with all of this money? Separate from the issues previously discussed, creating an increasingly prominent role for libraries could be an important policy lever in an indefinitely renewable framework. ${ }^{125}$ There are, under the current system, already incentives for copyright owners to register their works and deposit copies with the Register of Copyrights and the Library of Congress. ${ }^{126}$ But there are no comparable measures currently contained within the legal infrastructure that facilitate the distribution of copyright-protected works to public libraries. By redirecting money from renewal fees into the public library system (and fostering a broader, more efficient inter-library loan system), this new framework could ensure that all

${ }^{123}$ See Landes \& Posner, supra note 81, at 474 (noting that most copyrights rapidly depreciate in value).

${ }^{124}$ While determining the proper amount of the fees is beyond the scope of this Comment, it seems reasonable to assume that the cost of administering an indefinitely renewable copyright system could be supported by renewal fees. The rent-seeking behavior of copyright owners whose copyrights were about to expire before the passage of the Sonny Bono Copyright Term Extension Act suggests that, rather than lobby Congress for another extension every twenty years, they could just as easily spend that money paying renewal fees. See Landes \& Posner, supra note 81, at 483 (discussing rent-seeking behavior). Moreover, given that some intellectual properties are valued at over a billion dollars, it seems plausible that Congress could set ever-increasing renewal fees that ultimately reached into the millions. See, e.g., DAN RAVIV, COMIC WARS: MARVEL'S BATTLE FOR SURVIVAL 176-77 (2002) (recounting an industry insider's estimation that the intellectual property rights to the character Spider-Man were worth one billion dollars); David Rowan, A Small Bear with a Very Big Legal Bill, TIMES (U.K.), Nov. 22, 2003, at 40, available at 2003 WLNR 4977416 (noting that the intellectual property rights to the character Winnie the Pooh are estimated to be between one and five billion dollars).

${ }^{125}$ For a discussion on alternative ways libraries could be used to preserve culture, see Alicia Ryan, Note, Contract, Copyright, and the Future of Digital Preservation, 10 B.U. J. SCI. \& TECH. L. 152, 160-65 (2004). There are, of course, various First Amendment concerns that would follow from any reliance on the library system to disseminate all works to all patrons. See, e.g., David Norden, Note, Filtering out Protection: The Law, the Library, and Our Legacies, 53 CASE W. RES. L. REV. 767 (2003) (examining First Amendment issues surrounding the use of internet filtering software in public libraries to filter out pornography).

${ }^{126} 17$ U.S.C. $\$ \S 407,408$ (2000). Although the statute incentivizes both registration and deposit, in order to remain in compliance with the Berne Convention, neither is a requirement for acquiring copyright protection. See Berne Convention, supra note 47 , art. III (setting requirements for contracting states that require registration under their domestic law). 
copyrighted works are made available to the public for free immediately upon publication and registration. Indeed, while works in the public domain are theoretically possessed by the public at large, there is no guarantee that members of the public will actually have access to them. Just as the underlying idea of a copyrighted work vests with the public immediately, so too should the ability to access the copyrighted work vest immediately as well.

Ultimately, an indefinitely renewable term of copyright protection presents numerous advantages over the current system. While it is not clear whether the benefits of switching to such a scheme would ultimately outweigh the costs if the extant framework were to remain static, it seems likely that the current system will continue evolving in the same direction of ever-increasing terms of protection without any of the comparable benefits that would be derived from registration and renewal. An indefinitely renewable framework is preferable to this practice, in that it would better promote the utilitarian goals of copyright law.

\section{GIVE AND TAKE: FAIR USE AND DERIVATIVE WORKS}

Although copyright law has grown and evolved in numerous ways that have expanded the rights and benefits available to copyright holders (such as lengthening the term of protection ${ }^{127}$ and broadening the scope of protectable subject matter ${ }^{128}$ ), the legal precepts that have provided rights and benefits to the public (such as the fair use doctrine) have remained relatively unchanged since their inception. ${ }^{129}$ This Part argues that, in conjunction with the transition to a regime of indefinitely renewable copyright, complementary modifications to the scope of traditional copyright protection should also be instituted so as to balance more evenly the needs of copyright holders with those of content users.

${ }^{127}$ Compare Act of May 31, 1790, ch. 15, § 1, 1 Stat. 124 (providing a fourteen-year term of copyright protection, renewable for one additional fourteen-year term) (repealed 1831), with Sonny Bono Copyright Term Extension Act, Pub. L. No. 105-298, 112 Stat. 2827 (1998) (providing copyright protection for the life of the author plus seventy years).

${ }^{128}$ See, e.g., Act of Mar. 4, 1909, ch. 320, § 27, 35 Stat. 1175 (providing copyright protection for motion pictures) (repealed 1976); Act of Dec. 12, 1980, Pub. L. No. 96517, 94 Stat. 3015 (providing copyright protection for computer software).

${ }^{129}$ The fair use doctrine codified in the 1976 Act is substantially similar to Justice Story's formulation in Folsom v. Marsh, 9 F. Cas. 342 (C.C.D. Mass. 1841) (No. 4901). See Madison, supra note 32, at 1588 ("Folsom gave us the syntax of fair use."). 
As previously discussed, ${ }^{130}$ the derivative works and fair use doctrines evolved to determine which manner of non-identical copying fell within the exclusive rights afforded to authors and which were immediately permissible by the public. While recognition of derivative works protection addresses the problem of free riders who seek merely to capitalize on the creative output of an artist, ${ }^{131}$ the fair use doctrine seeks to carve out an exception for original works that draw in part on protected expressions.

The four factors that Congress instructed courts to consider in determining whether a use should be deemed 'fair' are

(1) the purpose and character of the use, including whether such use is of a commercial nature or is for nonprofit educational purposes;

(2) the nature of the copyrighted work;

(3) the amount and substantiality of the portion used in relation to the copyrighted work as a whole; and

(4) the effect of the use upon the potential market for or value of the copyrighted work. $^{132}$

Congress apparently intended to create a fluid standard that could be adapted to changing times. ${ }^{133}$ As a result, numerous courts ${ }^{134}$ and academics ${ }^{135}$ have struggled with the four factors' intrinsic ambi-

${ }^{130}$ See supra notes 21-35 and accompanying text (tracing the development of what courts considered to be copyright infringement).

${ }^{131}$ Such free rider exploitation would prevent authors from capturing the full value of their works, thus reducing authors' incentives to create works in the first place and possibly driving them out of the market.

${ }^{132} 17$ U.S.C. $\$ 107$ (2000). Although congressionally mandated, these factors are all derived from the judicially created fair use exception. See Madison, supra note 32, at 1588 (noting that Justice Story's Folsom opinion is "chiefly known [for] its formulation of what has come down to us as the four statutory fair use factors").

133 See H.R. REP. NO. 94-1476, at 66 (1976), reprinted in 1976 U.S.C.C.A.N. 5659, 5680 (noting that "there is no disposition to freeze the doctrine in the statute, especially during a period of rapid technological change," and further emphasizing that "courts must be free to adapt the doctrine to particular situations on a case-by-case basis").

134 See, e.g., A \& M Records, Inc. v. Napster, Inc., 239 F.3d 1004, 1014-17 (9th Cir. 2001) (applying the factors from the 1976 Act to the facts of the case against Napster); Am. Geophysical Union v. Texaco Inc., 60 F.3d 913, 918-32 (2d Cir. 1994) (analyzing the four factors from the 1976 Act in the context of the infringement action against Texaco).

${ }^{135}$ See, e.g., William W. Fisher III, Reconstructing the Fair Use Doctrine, 101 HARV. L. REV. 1659, 1669-86 (1988) (discussing the relative importance of the four factors); Gordon, supra note 34, at 1604 ("[T] he ambiguity of the fair use doctrine and its statutory formulation obscure the underlying issues and make consistency and predictabil- 
guity. The Supreme Court has most notably given guidance by stating that the fourth factor is "undoubtedly the single most important element of fair use." ${ }^{136}$ While some scholars have criticized this emphasis on the fourth factor, ${ }^{137}$ it can nevertheless be viewed as the magnetic pole of fair use analysis, and one might speculate that, as copyright protection evolves, the significance of the fourth factor will continue to grow to the point that perhaps the other factors become irrelevant. ${ }^{138}$ Complementing the argument in Part II that the copyright extension trend should be hastened into an indefinitely renewable copyright regime, this Part argues that such a scheme would best be served by taking the fair use trend towards emphasizing the fourth factor to its ultimate conclusion as well.

A chief concern with an indefinitely renewable framework is that certain types of expressions could be perpetually barred as infringing the copyright of protected works. A fair use test based solely on the fourth factor would ensure that the only expressions being suppressed were those that would act as a substitute for works already present in

ity difficult to achieve."); Madison, supra note 32, at 1550-64 (describing the interpretive difficulties posed by the statutory codification of the four factors).

${ }^{136}$ Harper \& Row, Publishers, Inc. v. Nation Enters., 471 U.S. 539, 566 (1985). But see Campbell v. Acuff-Rose Music, Inc., 510 U.S. 569, 579 (1994) ("[T] he more transformative the new work, the less will be the significance of other factors, like commercialism, that may weigh against a finding of fair use."). The Court in Campbell also noted that "the four statutory factors [may not] be treated in isolation, one from another. All are to be explored, and the results weighed together, in light of the purposes of copyright." Id. at 578 (citations omitted). While some lower courts have found significance in the Court's failure to reiterate the importance of the fourth factor, see, e.g., Am. Geophysical Union, 60 F.3d at 926 ("Apparently abandoning the idea that any factor enjoys primacy, Campbell instructs that '[a]ll [four factors] are to be explored, and the results weighed together..."' (citing Campbell, 510 U.S. at 578)), others have continued to give that factor preeminence, see, e.g., Princeton Univ. Press v. Mich. Document Servs., 99 F.3d 1381, 1385 (6th Cir. 1996) ("In determining whether a use is 'fair,' the Supreme Court has said that the most important factor is the fourth ....").

${ }^{137}$ See, e.g., Mark A. Lemley, The Economics of Improvement in Intellectual Property Law, 75 TEX. L. REV. 989, 1077 (1997) ("The problem has been the tendency of the courts to focus primarily on market harm to the copyright owner, to the exclusion of all else.").

${ }^{138}$ At least one scholar has suggested that the fourth factor alone is already determinative in fair use analysis. See 1 Melville Nimmer \& DAVID Nimmer, Nimmer on COPYRIGHT, $§ 1.10[\mathrm{D}]$, at 1-152 (1984) ("Fair use, when properly applied, is limited to copying by others that does not materially impair the marketability of the work that is copied." (footnote omitted)). 
the marketplace. ${ }^{139}$ In practice, this should result in a broader fair use doctrine, protecting a wider array of works while excluding only those that lack sufficient creativity to target a separate and distinct market.

However, this point highlights one of the problems inherent in a fourth factor analysis: determining the relevant market for the fair use analysis. A German translation of Uncle Tom's Cabin might have very little impact on the market for the English version. ${ }^{140}$ On the other hand, an audio recording of a novel might easily supplant the market demand for the paperback equivalent, yet there might simultaneously be a distinct demand for the audio recording itself. ${ }^{141}$ This problem exists due to the broad protection currently given to derivative works. Thus, the proposed modification to the fair use doctrine would best be achieved by simultaneously narrowing the scope of derivative works protection as well.

The simplest solution would be to stop extending copyright protection to derivative works entirely. Naomi Voegtli has suggested that such rights are not necessary for an author to profit from ancillary markets for her work. ${ }^{142}$ She argues that lead time (and thus the opportunity to create derivative works prior to publication), as well the ability to profit from goodwill associated with claims of authenticity (which non-authors would be barred from doing under laws of unfair competition), may provide sufficient compensation. ${ }^{143}$ However, this places a heavier burden on the author while primarily benefiting free riders, an odd direction in which to move the law. ${ }^{144}$ Ms. Voegtli of-

139 Moreover, these works would ideally be available via public libraries. See supra notes 125-26 and accompanying text (suggesting that copyright renewal fees be used to support the public library system).

${ }^{140}$ See supra notes 23-25 and accompanying text (discussing a court opinion rejecting an infringement claim based on a German translation of Uncle Tom's Cabin).

${ }^{141}$ For example, it seems likely that Michael Imperioli, a star of HBO's mafiathemed drama The Sopranos, was enlisted to record the audio version of Mario Puzo's mafia-themed novel Omerta at least partly in order to capitalize on a segment of the market that would not otherwise purchase the book. Mike Flaherty, Bold Soprano, ENT. WKLY., June 16, 2000 , at 87.

${ }^{142}$ Naomi Abe Voegtli, Rethinking Derivative Rights, 63 BROOK. L. REV. 1213, $1242-$ 43 (1997).

${ }^{143} I d$. at 1242 .

${ }^{144}$ While the benefit to free riders could conceivably trickle down to the public, as the commercialization of market substitutes would be likely to drive down prices and reduce deadweight loss, that benefit would be offset by the decreased incentive to create new works, and moreover, a comparable benefit (without the corresponding loss) could be achieved by making the actual works available for free through public libraries. See supra notes 125-26 and accompanying text (discussing the role that public libraries could play in an indefinitely renewable copyright scheme). 
fers a better solution to the line-drawing problem with her suggested redefinition of derivative work:

A "derivative work" is either (1) a work based significantly upon one or more pre-existing works, such that it exhibits little originality of its own or that it unduly diminishes economic prospects of the works used; or (2) a translation, sound recording, art reproduction, abridgement, and condensation. $^{145}$

This would scale nicely with the modified fair use analysis, providing protection to authors against derivative works that would act as a market substitute for the author's original expression, while still allowing follow-on artists to create new works inspired by existing art, so long as they were infused with sufficient originality. Under such a framework, West Side Story and Clueless would seem to be safe from claims of infringement. ${ }^{146}$

However, there would still be the question of how much a work's economic prospects would need to be diminished for it to rise to the level of being 'undue.' For example, even if one assumed that Bridget Jones's Diary ${ }^{147}$ contained the necessary level of creativity to distinguish it from Pride and Prejudice ${ }^{148}$ as a literary work, both novels have recently been adapted to films that were targeted at overlapping demographic groups. ${ }^{149}$ Thus, one might be tempted to argue for the seemingly perverse conclusion that the two films unduly compete for the same market in a way that the novels do not. Yet so long as the question of whether a 'borrowing' work infringes the original is answered solely by focusing on the fourth factor of the fair use analysis, any seemingly illogical results thereby produced would merely be reflections of the differences in the market for each medium of expression. ${ }^{150}$

${ }^{145}$ Voegtli, supra note 142, at 1267.

${ }^{146}$ See supra notes 109-15 and accompanying text (discussing works such as West Side Story and Clueless, which are adaptations of earlier pieces).

147 HELEN FIELDING, BRIDGET JONES's DiARY (1998).

148 Jane Austen, Pride And Prejudice (R.W. Chapman ed., Oxford Univ. Press 1960) (1813)

149 Compare BRIDGET JONES'S DIARY (Little Bird Ltd. 2001), with PRIDE AND PREJUDICE (Working Title Films 2005).

${ }^{150}$ The Supreme Court made roughly the same point in Campbell v. Acuff-Rose Music, Inc., noting that while 2 Live Crew's rap parody "Oh, Pretty Woman" did not infringe Roy Orbison's non-rap non-parody "Oh, Pretty Woman," it might nevertheless have harmed the market for a theoretical rap non-parody version of the song, and thus might still infringe Orbison's exclusive right to derivative versions of the work. 510 U.S. 569, 577-79 (1994). 
Moreover, so long as courts are vigilant in protecting the original work from market substitutes, this narrower conception of derivative works should not significantly diminish the incentive structure of copyright protection, even though it simultaneously provides the public with a wider array of creative expressions.

Finally, an ancillary concern with indefinitely renewable copyright protection is that it would heighten current problems that exist due to the ambiguity surrounding the contours of fair use. Professor Polk Wagner has convincingly argued that both copyright owners and appropriators are made worse off by the uncertainty of the doctrine. ${ }^{151}$ In addition, as new technologies develop and new uses for creative works arise, these uncertainties are magnified, and all parties experience a loss in perceived rights. ${ }^{152}$ However, this problem too could be solved by shifting to a fair use test that relies solely on the fourth factor; such a test would increase clarity and certainty, and thus the value of the works to all parties. ${ }^{153}$

Ultimately, an indefinitely renewable copyright regime should be paired with a modified conception of the proper scope of copyright protection. An emphasis on the fourth fair use factor would strengthen the economic incentive to create new works by providing stronger financial protection for those works, while simultaneously expanding the public domain by permitting any and all creative appropriations of those works that do not act as market substitutes. By pairing duration extension with a new derivative works/fair use paradigm, both copyright owners and follow-on artists would be able to extract valuable elements from the intellectual property without depriving the other of significant benefits.

\section{CAN'T BUY ME LOVE: \\ THE CONSTITUTIONALITY OF UNLIMITED TIMES}

The Intellectual Property Clause provides that Congress may grant exclusive rights to authors for "limited Times." ${ }^{154}$ In Eldred v. Ashcroft, the Supreme Court held that a single extension of retroactive copyright protection was not an attempt by Congress to "evade the 'limited

${ }^{151}$ See R. Polk Wagner, The Perfect Storm: Intellectual Property and Public Values, 74 FORDHAM L. REV. 423, 427 (2005) (arguing that the uncertainty surrounding the scope of copyright law has grown in recent years, potentially resulting in an erosion of fair use principles and the concomitant social benefits, creating a "perfect storm").

${ }^{152} I d$. at 429.

153 Id. at 434.

${ }^{154}$ U.S. CONST. art. I, $§ 8$, cl. 8. 
Times' constraint by creating effectively perpetual copyrights through repeated extensions, "155 but explicitly declined to address what might constitute the "outer boundary of "limited Times." "156 This Part speculates on the greatest extent of protection that might be permissible under the Intellectual Property Clause, as well as the possibility of circumventing its limitations through the Commerce Clause.

There is some historical evidence to suggest that the Limited Times Clause was not meant to be a restraint on Congress's power at all. By some accounts, the Clause was actually included simply to ensure that anyone interpreting the Constitution (especially those aware of the Framers' general aversion to monopolies) would understand that the power to grant patent and copyright monopolies was meant to be included within the subset of acts within Congress's power under the Intellectual Property Clause. ${ }^{157}$ Nevertheless, such a reading seems unlikely to carry the day, as it is clearly contrary to the Supreme Court's recent classification of the Clause as a constraint on Congress. ${ }^{158}$ Thus, the question should not be whether the Clause restrains Congress's power, but rather, how?

In its most literal sense, the "limited Times" restriction would be honored so long as copyright protection were granted for fixed terms of years. ${ }^{159}$ Indeed, the original draft of the Intellectual Property Clause allowed Congress to grant protection for "a limited time"; ${ }^{160}$ by amending the clause to instead read "limited Times," the Framers presumably intended to allow Congress to grant renewal terms. ${ }^{161}$ And in fact, renewal terms were an integral part of the copyright

${ }^{155} 537$ U.S. 186, 208 (2003).

${ }^{156} I d$. at 210 n.17 (2003); cf. 144 CONG. REC. H9952 (daily ed. Oct. 7, 1998) (statement of Rep. Mary Bono) ("Sonny wanted the term of copyright protection to last forever. I am informed by staff that such a change would violate the Constitution. . . As you know, there is also Jack Valenti's proposal for term to last forever less one day. Perhaps the Committee may look at that next Congress.”).

${ }^{157}$ See Edward C. Walterscheid, Conforming the General Welfare Clause and the Intellectual Property Clause, 13 HARV. J.L. \& TECH. 87, 96 (1999) (arguing that "the additional language is there because without it the delegates did not believe Congress would have authority to grant patents and copyrights, regardless of how broad the authority 'to promote the progress of science and useful arts' might on its face appear").

${ }^{158}$ Eldred, 537 U.S. at 208.

${ }^{159}$ Landes \& Posner, supra note 81, at 472.

${ }^{160}$ See George Ramsey, The Historical Background of Patents, 18 J. PAT. OFF. Soc'y 6, 14 (1936) ("The original manuscript of [a] draft of the Constitution . . . discloses that the original draft included the words 'for a limited time."')

${ }^{161}$ See id. ("There is no record as to why [the change in the 'limited Times' language] was made but we might guess that it was done for the purpose of permitting a patent to be extended."). 
scheme from 1790 to 1976 . Thus, even a system of indefinitely renewable copyright might be permissible under the Intellectual Property Clause. ${ }^{162}$ Nevertheless, this reading runs up against the problem that the Framers seem to have clearly imagined that works protected by this Clause would eventually fall into the public domain. ${ }^{16}$

What, then, of extending copyright protection through another grant of power, such as the Commerce Clause? ${ }^{164}$ The Supreme Court has generally been skeptical of congressional attempts to do with one power that which it has been explicitly barred from doing with another. ${ }^{165}$ Thus, the Court has read limitations into the Commerce Clause from the Bankruptcy Clause, ${ }^{166}$ the Fifth Amendment's Due Process Clause, ${ }^{167}$ the Sixth Amendment's right to trial by jury, ${ }^{168}$ and

${ }^{162}$ See Landes \& Posner, supra note 81, at 472 (postulating that the constitutional limitation may be circumvented by allowing repeated extensions of the copyright term). But see Malla Pollack, Unconstitutional Incontestability? The Intersection of the Intellectual Property and Commerce Clauses of the Constitution: Beyond a Critique of Shakespeare Co. v. Silstar Corp., 18 SEATtLE U. L. REV. 259, 286 (1995) (arguing that such a reading is "conceivable, but strained").

${ }^{163}$ See Nachbar, supra note 72, at 330 n.251 (collecting sources).

${ }^{164}$ The Supreme Court has clearly established that Congress may use the Commerce Clause to protect certain forms of intellectual property that may not be protected by the Intellectual Property Clause, such as trademarks. See The Trade-Mark Cases, 100 U.S. 82, 97 (1879) (striking down a federal trademark statute as unconstitutional, but suggesting the possibility that a narrowly tailored statute limited to marks used in interstate commerce would be acceptable); see also Lanham Trade-Mark Act, 15 U.S.C. $§ 1051$ (2000) (limiting trademark protection to marks used in commerce); New Kids on the Block v. News Am. Publ'g, Inc., 971 F.2d 302, 305 (9th Cir. 1992) (" $[\mathrm{T}]$ rademarks have been covered by a comprehensive federal statutory scheme since the passage of the Lanham Act in 1946”). Moreover, intellectual property protection granted under the Commerce Clause could theoretically be infinite in duration. See Dan Hunter, Culture War, 83 TEX. L. REv. 1105, 1109 n.24 (2005) ("Trademarks are capable of infinite term since they may be repeatedly renewed.").

${ }^{165}$ See, e.g., EEOC v. Wyoming, 460 U.S. 226, 248 (1983) (Stevens, J., concurring) ("Congress may not ... transcend specific limitations on its exercise of the commerce power that are imposed by other provisions of the Constitution.”); see generally Pollack, supra note 162, at 270-74 (arguing that Congress does not have the power to bypass the Intellectual Property Clause through the Commerce Clause).

${ }^{166}$ See, e.g., Ry. Labor Executives' Ass'n v. Gibbons, 455 U.S. 457, 468-69 (1982) (holding that Congress may not use the Commerce Clause to pass a non-uniform bankruptcy law because the Bankruptcy Clause requires bankruptcy laws to be uniform).

${ }^{167}$ See, e.g., Leary v. United States, 395 U.S. 6, 29-53 (1969) (holding that a provision of the Narcotic Drugs Import and Export Act was unconstitutional because it violated the Fifth Amendment).

${ }^{168}$ See, e.g., United States v. Jackson, 390 U.S. 570, 582 (1968) ("Whatever might be said of Congress' objectives, they cannot be pursued by means that needlessly chill the exercise of basic constitutional rights." (citations omitted)). 
notions of state sovereignty inherent in the Tenth Amendment. ${ }^{169}$ Justice O'Connor has also suggested that limitations may be found in the Twenty-first Amendment. ${ }^{170}$

On the other hand, the Court has also noted that certain enumerated powers may simply overlap, and in those situations, restrictions on the exercise of one power do not constrain Congress's ability to act pursuant to another. ${ }^{171}$ For instance, the Court found that Congress could circumvent the limitations of the Tax Clause-that all taxes be "for the common Defence and general Welfare of the United States" ${ }^{172}$ - by enacting tax legislation through the Commerce Clause. ${ }^{173}$ This view, that the General Welfare Clause did not limit the Commerce Clause, is especially significant given the close parallel between the General Welfare Clause and the Promote Progress Clause. ${ }^{174}$ In both cases, the Constitution grants Congress the power to achieve an abstract goal and delineates a particular method by which that ultimate goal might be achieved. Thus, just as the Su-

${ }^{169}$ See Garcia v. San Antonio Metro. Transit Auth., 469 U.S. 528, 555-56 (1985) (noting that states "occupy a special and specific position in our constitutional system and that the scope of Congress' authority under the Commerce Clause must reflect that position").

${ }^{170}$ See South Dakota v. Dole, 483 U.S. 203, 218 (1987) (O'Connor, J., dissenting) (" $[\mathrm{T}]$ he regulation of the age of the purchasers of liquor ... falls squarely within the scope of those powers reserved to the States by the Twenty-first Amendment." (citation omitted)). The majority resolved the issue under the Spending Power and thus did not reach the issue of the Twenty-first Amendment. Id. at 206.

${ }^{171}$ The question of whether two grants of power overlap or if one limits the other is generally resolved by an inquiry into whether an enumerated power contains an "affirmative" or "positive" limitation. See Nachbar, supra note 72, at 294-98; see also Paul J. Heald \& Suzanna Sherry, Implied Limits on the Legislative Power: The Intellectual Property Clause as an Absolute Constraint on Congress, 2000 U. ILL. L. REV. 1119, 1124 (drawing a distinction between those cases in which Congress "runs into barriers" from those in which "Congress's power just runs out").

${ }^{172}$ U.S. CONST. art. I, § 8, cl. 1.

${ }^{173}$ See Edye v. Robertson (Head Money Cases), 112 U.S. 580, 594 (1884) (holding that Congress had the power to pass a law regulating immigration under its commerce power and did not violate any other part of the Constitution in doing so). The case remains viable for the proposition that taxes not levied for the "common defence and general welfare"” are not an exercise of " the taxing power" but rather "'the mere incident of the regulation of commerce." Union Pac. R.R. Co. v. Pub. Utility Comm'n, 899 F.2d 854, 858 (9th Cir. 1990) (quoting Head Money Cases, 112 U.S. at 595)

${ }^{174}$ See Walterscheid, supra note 157. Admittedly, this argument relies on stale case law, as the 1913 ratification of the Sixteenth Amendment provided Congress with a broad taxing power unrestrained by the General Welfare Clause. Nevertheless, the Supreme Court has held that the General Welfare Clause should be viewed as a "grant of power" rather than as "a limitation upon congressional power." Buckley v. Valeo, 424 U.S. 1, 90 (1976). 
preme Court has found that taxes enacted outside the scope of the General Welfare Clause may nevertheless be permissible under the Commerce Clause, the door might similarly be open for copyright protection beyond the Intellectual Property Clause to be properly justified under the Commerce Clause.

Professor Thomas Nachbar has argued for the general proposition that the Intellectual Property and Commerce Clauses should be viewed as overlapping grants of power and that the explicit constraints in the Intellectual Property Clause should not be viewed as "affirmative" limitations on other enumerated powers. ${ }^{175}$ However, he nevertheless concedes that "there is a stronger textual argument for applying the 'limited Times' restriction to the whole of Section 8 than there is for any of the Intellectual Property Clause's other limits." ${ }^{\text {176 }}$ Other scholars have similarly concluded that the Commerce Clause may not be used to circumvent the "limited Times" provision. ${ }^{177}$

By most indications, such a move would be met with judicial skepticism as well. Already, the Eleventh Circuit, analyzing an antibootlegging statute passed under the Commerce Clause, suggested in dicta that "the Commerce Clause could not be used to avoid a limitation in the Copyright Clause if the particular use of the Commerce Clause (e.g., the anti-bootlegging statute) were fundamentally inconsistent with the particular limitation in the Copyright Clause (e.g., the fixation requirement)."

${ }^{175}$ Nachbar, supra note 72, at 297.

${ }^{176} I d$.

${ }^{177}$ See, e.g., Pollack, supra note 162, at 270-99 (arguing that the Commerce Clause cannot be used to grant exclusive rights in a way that undermines the explicit "limited Times" language in the Promote Progress Clause); see also Heald \& Sherry, supra note 171 (arguing that the individual constraints of the Intellectual Property Clause may not be circumvented through the use of other enumerated powers).

${ }^{178}$ United States v. Moghadam, 175 F.3d 1269, 1280 n.12 (11th Cir. 1999). Although this portion of the opinion states that the fixation requirement is inherently contained in the Constitution's use of the term "Writings," elsewhere the court notes that it is assuming this position arguendo but deciding the case on other grounds. Id. at 1277; see also supra note 72 (discussing the fixation requirement).

The Southern District of New York more directly confronted the issue of whether the anti-bootlegging statute could be supported by the Commerce Clause and concluded that it could not. See United States v. Martignon, 346 F. Supp. 2d 413, 424-29 (S.D.N.Y. 2004) (holding the anti-bootlegging statute unconstitutional because it directly violates both the Copyright Clause's fixation and durational restrictions). 
Nevertheless, the Eleventh Circuit upheld the anti-bootlegging statute, ${ }^{179}$ and courts have been similarly generous in their appraisal of Congress's ability to provide copyright-like protection via the Commerce Clause, most notably with the DMCA. ${ }^{180}$ Despite substantial skepticism, ${ }^{181}$ courts have consistently upheld the statute in the face of constitutional challenges arguing that its protection violates the Article I, Section 8 "limited Times" constraint. ${ }^{182}$

Moreover, courts have recognized in other contexts that the Intellectual Property Clause does not act as a restraint on Congress's other powers. For example, in Constant v. Advanced Micro-Devices, Inc., the Federal Circuit held that the Intellectual Property Clause, by empowering Congress to promote progress through the grant of patents and copyrights, did not prevent Congress from promoting progress through other means, such as government sponsorship of research and development. ${ }^{183}$

Finally, there is a fundamental structural constraint on the term "limited Times." Congress is not simply empowered to grant copyrights, but rather " $[\mathrm{t}] \mathrm{o}$ promote the Progress of Science and useful Arts," ${ }^{184}$ with the ability to secure copyrights "for limited Times" ${ }^{\prime 185}$ provided as a means to that end. ${ }^{186}$ Thus, if Congress were explicitly acting to pursue a different philosophical end, such as protecting the

179 See Moghadam, 175 F.3d at 1271 (“[W]e reject Moghadam’s constitutional challenge, and therefore affirm Moghadam's conviction.”). Contra Martignon, 346 F. Supp. $2 \mathrm{~d}$ at 429-30 (concluding that the anti-bootlegging statute is unconstitutional).

${ }^{180}$ Pub. L. No. 105-304, 112 Stat. 2860 (1998); see supra notes 66-67 and accompanying text (discussing the DMCA).

${ }^{181}$ See, e.g., Joshua Schwartz, Thinking Outside the Pandora's Box: Why the DMCA Is Unconstitutional Under Article 1, \& 8 of the U.S. Constitution, 10 J. TECH. L. \& POL'Y 93, 96 (2005) (arguing that, by allowing copyright holders to prevent the public from ever copying a work, the DMCA is in "direct contravention of the limited times" provision of the Constitution).

${ }^{182}$ See, e.g., Universal City Studios, Inc. v. Corley, 273 F.3d 429, 444-45 (2d Cir. 2001) (refusing to disturb the district court's grant of an injunction under the DMCA despite appellants' challenge based on the Copyright Clause); United States v. Elcom Ltd., 203 F. Supp. 2d 1111, 1137-42 (N.D. Cal. 2002) (upholding the DMCA against a constitutional challenge because it was within Congress's commerce power and was not irreconcilably inconsistent with any provision of the Intellectual Property Clause).

${ }^{183} 848$ F.2d 1560, 1564-65 (Fed. Cir. 1988) ("Ample constitutional power for Government funding of research and development can be found in art. I, § 8, cl. 1 (provide for the common Defense and general Welfare), cl. 3 (Commerce), cl. 12 (Army), cl. 13 (Navy) and cl. 18 (necessary and proper clause).”).

${ }^{184}$ U.S. CONST. art. I, $\$ 8$, cl. 8.

${ }^{185} I d$.

${ }^{186}$ Walterscheid, supra note 157 , at 125. 
'moral rights' of artists, ${ }^{187}$ then the "limited Times" constraint would not necessarily be applicable. ${ }^{188}$

Promulgating an indefinitely renewable copyright scheme under the Commerce Clause would philosophically harmonize the system with the modified conception of copyright protection proposed in Part III, which measures the metes and bounds of that protection solely by analyzing the market substitution effects of potentially infringing works. Moreover, a Commerce Clause scheme would be more or less limited to governing only those works sold through channels of interstate commerce, ${ }^{189}$ which would be a minuscule fraction of the works that currently receive federal protection through statutes promulgated pursuant to the Intellectual Property Clause. Thus, a Commerce Clause copyright system could act concurrently with the current Intellectual Property Clause copyright framework, with qualifying works eligible for protection under either statutory scheme.

At its heart, indefinitely renewable copyright hinges on the finding that extending the duration of protection would promote the consequentialist goals of copyright law. The ultimate purpose of the Limited Times Clause is, after all, to provide Congress with the power to satisfy the utilitarian Promote Progress Clause. ${ }^{190}$ Thus, whether an indefinitely renewable copyright scheme were to be promulgated under either the Intellectual Property Clause or the Commerce Clause,

187 See supra note 63 (discussing 'moral rights').

188 See Moral Rights in Our Copyright Laws: Hearings on S. 1198 and S. 1253 Before the Subcomm. on Patents, Copyrights and Trademarks of the S. Comm. on the Judiciary, 101st Cong. 38-39 (1989) (statement of Edward J. Damich, Associate Professor, George Mason University) (arguing that 'moral rights' do not fall under the auspices of the Intellectual Property Clause and thus could be granted for an infinite duration); Edward J. Damich, The Visual Artists Rights Act of 1990: Toward a Federal System of Moral Rights Protection for Visual Art, 39 CATH. U. L. REV. 945, 993 (1990) ("[A]lthough the Copyright Clause of the United States Constitution speaks of 'limited times,' moral rights arguably are not strictly copyright rights, that is, economic rights. Therefore, moral rights could last in perpetuity. Furthermore, insofar as moral rights protection indirectly benefits art preservation, perpetual protection is appropriate.").

189 See United States v. Morrison, 529 U.S. 598, 608-09 (2000) (discussing the limits of Congress's power under the Commerce Clause); United States v. Lopez, 514 U.S. 549, 558-59 (1995) (same).

${ }^{190}$ The meaning of "progress" nevertheless remains subject to dispute, with both authors and putative infringers claiming that their use of a copyrighted work furthers the ultimate goal of the Clause. See John D. Shuff \& Geoffrey T. Holtz, Copyright Tensions in a Digital Age, 34 AKRON L. REV. 555, 555-56 (2001) (explaining that authors argue that copyright provides an economic incentive to create works and that infringers argue that progress is promoted by the most widespread public dissemination of works). 
there would be a strong structural argument against binding Congress to a narrow interpretation of "limited Times" that undermined its ability to simultaneously benefit both copyright owners and content users. If one were to accept that these two clauses were in conflict, it seems reasonable to conclude that the "limited Times" constraint should be interpreted in a manner subservient to the Promote Progress Clause.

\section{CONCLUSION}

Copyright law is evolving along several clear axes. Based on its current trajectories, the duration of protection will continue to grow while the fourth factor will increasingly dominate fair use analysis. These trends should be carried out to their ultimate bounds, in a scheme that permits copyrights to be renewed an unlimited number of times, but provides protection only against works that would act as market substitutes for the original. Such a framework presents numerous advantages over the current system, especially if Congress continues its practice of granting retroactive copyright extensions each time the extant term is about to expire. Ultimately, the proposed schema seeks to maximize social wealth by reconceptualizing and reallocating the rights associated with copyright protection, providing both copyright owners and content users with increased protection for the rights that they value most. 